\section{Kidney \\ Blood Pressure Research}

\title{
Sex Differences in the Prevalence, Progression, and Improvement of Chronic Kidney Disease
}

\author{
Kazuyoshi Okadaa,b Mitsuru Yanai ${ }^{\mathrm{a}, \mathrm{c}}$ Kazuhisa Takeuchia ${ }^{\mathrm{a}, \mathrm{d}} \quad$ Kazuhiro Matsuyama ${ }^{\mathrm{a}, \mathrm{e}}$ \\ Kosaku Nitta ${ }^{a}$, Kenji Hayashig Susumu Takahashia \\ aInternational Kidney Evaluation Association Japan, \#702 Ichigaya Linden Bldg., 3-25 Ichigayahonmura- \\ cho, Shinjuku-ku; 'bivision of Nephrology, Hypertension and Endocrinology, Department of Medicine, \\ Nihon University School of Medicine, 30-1 Oyaguchi-kamicho, Itabashi-ku; 'Division of General \\ Medicine, Department of Medicine, Nihon University School of Medicine, 30-1 Oyaguchi-kamicho, \\ Itabashi-ku, Tokyo 173-8610; 'Koujinkai Chuo Clinic, 2-1-6 Tsutsujigaoka, Miyagino-ku, Sendai-shi,

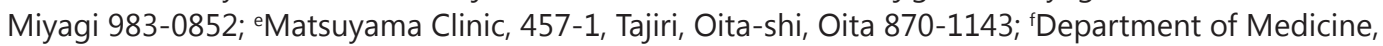 \\ Kidney Center, Tokyo Women's Medical University, 8-1 Kawada-cho, Shinjuku-ku, Tokyo 162-8666; \\ 9National Institute of Public Health, 2-3-6 Wako-shi Minami, Saitama 351-0197, Japan
}

\section{Key Words}

Chronic kidney disease $\cdot$ Women $•$ Anemia $・$ Albuminuria

\begin{abstract}
Background/Aims: We examined sex differences in prevalence, progression, and improvement in early-stage chronic kidney disease (CKD). Methods: We analyzed data from 533 participants who took 4 consecutive annual CKD detection tests. Results: Urine albumin-creatinine ratio $(A C R)$, estimated glomerular filtration rate (eGFR), and hemoglobin $(\mathrm{Hb})$ at baseline in men with and without CKD and in women with and without CKD were 8.3 $\pm 6.1,149.2 \pm 310.4,10.2 \pm 5.8$, and $96.7 \pm 246.8 \mathrm{mg} / \mathrm{g} \mathrm{Cr} ; 83.4 \pm 14.7,63.8 \pm 18.8,79.9 \pm 13.0$, and $69.4 \pm 20.0 \mathrm{~mL} / \mathrm{min} / 1.73 \mathrm{~m}^{2}$; and $14.8 \pm 1.2,14.3 \pm 1.4,13.0 \pm 1.0$, and $13.0 \pm 1.2 \mathrm{mg} / \mathrm{dL}$, respectively. ACR levels decreased significantly over time in men and women with CKD and they increased significantly over time in men and women without CKD. eGFR levels in men and women with CKD did not significantly change over time, but they decreased significantly over time in men and women without CKD. CKD prevalence and progression rate were not significantly different between sexes. Among the CKD participants, significantly more women had a "cured" status at 3 years ( $39.1 \%$ vs. $19.4 \%, P<0.01$ ). Most whose eGFR increased to $>60 \mathrm{~mL} / \mathrm{min} / 1.73 \mathrm{~m}^{2}$ at 3 years had values just below those at baseline. Regression analysis showed that change in eGFR correlated significantly with ACR in men with CKD (change in eGFR $=-1.707+0.022 \times A C R$, $P<0.001, r^{2}=0.201$ ) and with $\mathrm{Hb}$ and $\mathrm{ACR}$ in women with CKD (change in eGFR =
\end{abstract}




\section{Kidney Blood Pressure Research}

Kidney Blood Press Res 2014;39:279-288

DOI: 10.1159/000355805

Publisned oninne: August 23, 2014

(c) 2014 S. Karger AG, Basel

www.karger.com/kbr

48.870-3.803 $\left.\times \mathrm{Hb}+0.018 \times \mathrm{ACR}, P<0.05, r^{2}=0.134\right)$. Conclusions: These results suggest that the slight decrease of $\mathrm{Hb}$ within a normal range and mild anemia can be managed in women with early-stage CKD. The key baseline for eGFR is $60 \mathrm{~mL} / \mathrm{min} / 1.73 \mathrm{~m}^{2}$.

Copyright $\odot 2014$ S. Karger AG, Basel

\section{Introduction}

The increasing prevalence of chronic kidney disease (CKD) and its adverse outcomes, such as cardiovascular disease (CVD) and death, and the high cost of treatment are major public health problems worldwide [1-3]. The International Kidney Evaluation Association Japan (IKEAJ) has been working to improve public health awareness of CKD. The costfree IKEAJ CKD detection program comprises a questionnaire, physical examination, and laboratory tests described in detail elsewhere [4]. Epidemiologic studies have raised awareness of the risk factors for onset and progression of CKD in the general population.

In the Japanese general population, the prevalence of newly developed CKD over 10 years was reported to be $19.2 \%$ among adults over 40 years of age, and levels of blood pressure (BP), blood glucose (BG), and serum lipid, obesity, smoking, and alcohol consumption affected the development of CKD [5]. However, the prevalence of CKD may have been underestimated in that study because the urine albumin-creatinine ratio (ACR) was not measured. In our recent study measuring ACR, we reported a CKD prevalence of $26.7 \%$ [4].

The population of Japan in 2013 was 127, 410, 000 (61, 971, 000 men, 65, 441, 000 women). Japanese patients undergoing dialysis in 2010 numbered 289, 449 (180, 120 men, 109, 329 women); among them, 37, 238 (24, 660 men and 12, 578 women) started dialysis and 27, 241 (17, 413 men, 9, 828 women) died that year [6]. Thus, men outnumbered women in all instances, despite the slightly higher ratio of women to men in the general population. These differences between sexes suggest that differences in lifestyle affect both survival and the incidence and progression of CKD.

This study retrospectively compared sex differences in the prevalence, progression, and improvement of CKD among participants in the IKEAJ program to examine the effectiveness of the program and suggest future directions for CKD screening and management in Japan.

\section{Patients and Methods}

\section{Participants}

Participants in the IKEAJ program were aged 15 years or older with self-reported diabetes mellitus (DM) or hypertension (HT) or a family history of DM, HT, or kidney disease. This report describes 533 of the first 2618 program participants who received 4 consecutive yearly examinations in the program from June 2006 through November 2011. The program was carried out at 13 Japanese clinics and medical centers in accordance with the relevant laws and regulations.

Informed consent was obtained from all program participants, and the Institutional Review Board approved this study, which was conducted in accordance with the Declaration of Helsinki of 1975 (as revised in 2005).

\section{Data collection}

Tests and measurements included height, weight, waist circumference, BP, creatinine (Cr), BG, serum high-density lipoprotein-cholesterol (HDL-C), serum low-density lipoprotein-cholesterol (LDL-C), hemoglobin A1c (HbA1c), hemoglobin (Hb) and ACR (spot urine). Body mass index (BMI) and estimated glomerular filtration rate (eGFR) according to an equation validated for the Japanese population [7] were calculated. BP was measured bilaterally in the sitting position. All laboratory tests were performed with samples collected during the medical examination and sent on the same day to a central laboratory vendor (SRL, Inc., Tokyo, Japan). 


\section{Kidney Blood Pressure Research}

Kidney Blood Press Res 2014;39:279-288

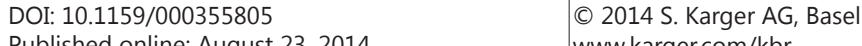

Publisned onitne: August 23, 2014

www.karger.com/kbr

Okada/Yanai/Takeuchi/Matsuyama/Nitta/Hayashi/Takahashi: Relationship Between Hemoglobin and eGFR in Women

Normal range and reference values

Reference values considered to positively indicate poorly controlled BP, BG, and LDL-C were considered to be $140 / 90 \mathrm{mmHg}$ for $\mathrm{BP}$, either BG value of $200 \mathrm{mg} / \mathrm{dL}$ or $\mathrm{HbA1c} \geq 6.5 \%$ for $\mathrm{BG}$, and $\geq 140 \mathrm{mg} / \mathrm{dL}$ for LDL-C. Normal participants were considered stage 0 in the IKEAJ program.

\section{Statistical analysis}

Results are expressed as mean \pm standard error (SE) values. We assessed differences in the same group with the $t$-test for paired data. The unpaired $t$-test was used to compare mean values between groups. The chi-squared test was used to compare differences between groups. Repeated ANOVA was used to compare median changes between groups. In addition, regression analysis was performed using a dependent variable (change in eGFR over 3 years) and independent variables (waist circumference, BMI, systolic blood pressure (SBP), diastolic blood pressure (DBP), ACR, Hb, HbA1c, HDL-C, and LDL-C at baseline). SPSS ver. 20 was used for statistical analysis. Significance was established at a level of $P<0.05$.

\section{Results}

\section{Participants}

The CKD prevalence was not significantly different between men and women, at $27.7 \%$ and $28.2 \%$, respectively. Because many differences existed between sexes in participants with and without CKD (Table 1), it is important to examine the influence of sex on CKD prevalence and progression.

\section{Changes in blood pressure, blood glucose, and low-density lipoprotein-cholesterol}

Table 2 shows the changes of participants with poorly controlled BP, BG, and LDL-C over 3 years. In regard to poor-controlled BP, more hypertensive participants with CKD at baseline had a previous diagnosis of HT more than those without CKD in both men $(P<0.01)$ and women $(P<0.05)$. In relation to poor-controlled $B G$, there was no significant difference in diagnosis at baseline between diabetic participants with CKD and those without CKD in either men or women. As for poor-controlled LDL-C, significantly more female participants with CKD and dyslipidemia at baseline had a previous diagnosis of dyslipidemia compared to participants without CKD $(P<0.05)$.

SBP and DBP in men and women with and without CKD decreased significantly over time (Fig. 1). There was no significant difference in BP between men with and without CKD. SBP and DBP in women with CKD were significantly higher than those in women without CKD. HbA1c levels in men without CKD and women with and without CKD increased significantly over time (Fig. 2). Although the LDL-C levels in men and women with CKD decreased significantly over time, there was no significant difference in LDL-C in men or women without CKD (Fig. 3).

\section{Changes in albumin-creatinine ratio and estimated glomerular filtration rate}

ACR levels in men and women with CKD decreased significantly over time, except among men at 3 years. On the other hand, they increased significantly over time among men and women without CKD (Fig. 4). eGFR levels in men and women with CKD did not significantly change over time. In contrast, eGFR levels decreased significantly over time in men and women without CKD (Fig. 5). It is important to note that ACR levels were decreased while eGFR levels were not decreased in many patients with CKD during the 3-year follow up. In regard to CKD participants at baseline, significantly more women than men achieved a cured status at 3 years (Table 3). In cured cases in women, the levels of BMI, SBP, DBP, Hb, LDL, and ACR were significantly decreased and the level of HbA1c was significantly increased at 3 years compared to their respective levels at baseline. However, in men, no parameters were significantly changed (Table 4). Figure 6 shows the changes in ACR (a) and eGFR (b) in cured cases of CKD. Most men and women with eGFR that increased to $>60 \mathrm{~mL} / \mathrm{min} / 1.73 \mathrm{~m}^{2}$ at 3 years had baseline eGFR values just below $60 \mathrm{~mL} / \mathrm{min} / 1.73 \mathrm{~m}^{2}$. eGFR was improved in 


\section{Kidney \\ Blood Pressure Research}

Table 1. Baseline values for participants with 4 consecutive yearly evaluations in the International Kidney Evaluation Japan chronic kidney disease detection program

\begin{tabular}{|c|c|c|c|c|c|c|}
\hline & \multicolumn{3}{|c|}{ Men $(n=224)$} & \multicolumn{3}{|c|}{ Women $(n=309)$} \\
\hline & $\begin{array}{l}\text { CKD (-) } \\
n=162\end{array}$ & $\begin{array}{c}\mathrm{CKD}(+) \\
n=62\end{array}$ & P value & $\begin{array}{l}\text { CKD (-) } \\
n=222\end{array}$ & $\begin{array}{c}\mathrm{CKD}(+) \\
\mathrm{n}=87\end{array}$ & $\mathrm{P}$ value \\
\hline Age (years) & $51.8 \pm 19.1$ & $65.6 \pm 11.8$ & $\mathrm{P}<0.001$ & $56.0 \pm 14.2^{*}$ & $65.4 \pm 13.3$ & $\mathrm{P}<0.001$ \\
\hline \multicolumn{7}{|l|}{ Past history } \\
\hline Hypertension (\%) & 36.9 & 71.0 & $\mathrm{P}<0.001$ & 31.7 & 62.8 & $\mathrm{P}<0.001$ \\
\hline Diabetes mellitus (\%) & 23.6 & 32.8 & ns & $14.1^{*}$ & 25.9 & $\mathrm{P}<0.05$ \\
\hline $\begin{array}{l}\text { No hypertension or diabetes } \\
\text { mellitus (\%) }\end{array}$ & 52.5 & 19.4 & $\mathrm{P}<0.01$ & 60.8 & 32.2 & $\mathrm{P}<0.001$ \\
\hline Cardiovascular disease (\%) & 19.1 & 27.4 & ns & 12.2 & 25.3 & $\mathrm{P}<0.01$ \\
\hline \multicolumn{7}{|l|}{ Family history } \\
\hline Hypertension (\%) & 36.5 & 48.3 & ns & $48.9^{*}$ & 55.8 & ns \\
\hline Diabetes mellitus (\%) & 25.9 & 33.9 & ns & 26.8 & 27.1 & ns \\
\hline Kidney disease (\%) & 9.9 & 10.3 & ns & 16.6 & 15.1 & ns \\
\hline \multicolumn{7}{|l|}{ Smoking } \\
\hline Smoker (\%) & 20.5 & 14.5 & ns & $9.9^{*}$ & 7.0 & ns \\
\hline Quitter (\%) & 36.0 & 50.0 & ns & $78.4^{*}$ & $83.7^{*}$ & ns \\
\hline Nonsmoker (\%) & 43.5 & 35.5 & ns & $11.7^{*}$ & $9.3^{*}$ & ns \\
\hline Total number of cigarettes & $209,160.6 \pm$ & $299,168.6 \pm$ & $\mathrm{P}<0.01$ & $90,440.7 \pm$ & $93,600.0 \pm$ & ns \\
\hline smoked & $192,536.4$ & $153,381.3$ & & $80,035.8^{* * *}$ & $107,219.0^{* * *}$ & \\
\hline Alcohol (\%) & 81.5 & 93.5 & $\mathrm{P}<0.05$ & $57.2^{* * *}$ & $48.8^{* * *}$ & ns \\
\hline Body mass index $\left(\mathrm{kg} / \mathrm{m}^{2}\right)$ & $25.0 \pm 4.1$ & $25.4 \pm 3.9$ & ns & $21.7 \pm 3.3^{* * *}$ & $23.7 \pm 3.8^{* *}$ & $\mathrm{P}<0.001$ \\
\hline Waist circumstance $(\mathrm{cm})$ & $86.8 \pm 10.2$ & $88.3 \pm 10.2$ & ns & $77.5 \pm 10.4^{* * *}$ & $84.5 \pm 11.5^{*}$ & $\mathrm{P}<0.001$ \\
\hline Systolic blood pressure (mmHg) & $134.3 \pm 17.2$ & $135.8 \pm 15.9$ & ns & $127.0 \pm 19.2^{* * *}$ & $137.8 \pm 22.8$ & $P<0.001$ \\
\hline $\begin{array}{l}\text { Diastolic blood pressure } \\
\text { (mmHg) }\end{array}$ & $74.6 \pm 11.1$ & $77.8 \pm 11.7$ & ns & $71.7 \pm 11.5^{*}$ & $77.0 \pm 10.9$ & $\mathrm{P}<0.001$ \\
\hline Hemoglobin (g/dL) & $14.8 \pm 1.2$ & $14.3 \pm 1.4$ & $\mathrm{P}<0.05$ & $13.0 \pm 1.0^{* * *}$ & $13.0 \pm 1.2^{* * *}$ & ns \\
\hline HDL cholesterol (mg/dL) & $53.5 \pm 13.2$ & $50.0 \pm 13.8$ & ns & $65.9 \pm 17.0^{* * *}$ & $60.0 \pm 17.0^{* * *}$ & $\mathrm{P}<0.01$ \\
\hline LDL cholesterol (mg/dL) & $115.2 \pm 28.3$ & $116.6 \pm 25.6$ & ns & $119.5 \pm 29.1$ & $125.0 \pm 28.3$ & ns \\
\hline Hemoglobin A1c (\%) & $5.6 \pm 0.7$ & $6.1 \pm 1.1$ & $\mathrm{P}<0.05$ & $5.5 \pm 0.7$ & $5.7 \pm 0.7$ & ns \\
\hline Creatinine (mg/dL) & $0.80 \pm 0.10$ & $0.99 \pm 0.24$ & $\mathrm{P}<0.001$ & $0.61 \pm 0.73^{* * *}$ & $0.70 \pm 0.18^{* * *}$ & $\mathrm{P}<0.001$ \\
\hline $\begin{array}{l}\text { Estimated glomerular filtration } \\
\text { rate }\left(\mathrm{mL} / \mathrm{min} / 1.73 \mathrm{~m}^{2}\right)\end{array}$ & $83.4 \pm 14.7$ & $63.8 \pm 18.8$ & $\mathrm{P}<0.001$ & $79.9 \pm 13.0^{*}$ & $69.4 \pm 20.0$ & $\mathrm{P}<0.001$ \\
\hline $\begin{array}{l}\text { Urinary albumin excretion } \\
\text { (mg/g Cr) }\end{array}$ & $8.3 \pm 6.1$ & $149.2 \pm 310.4$ & $\mathrm{P}<0.001$ & $10.2 \pm 5.8$ & $96.7 \pm 246.8$ & $\mathrm{P}<0.01$ \\
\hline Prevalence rate of CKD (\%) & 0 & 100 & $\mathrm{P}<0.001$ & 0 & 100 & $\mathrm{P}<0.001$ \\
\hline Stage 1 & 0 & 14.5 & & 0 & 17.2 & \\
\hline Stage 2 & 0 & 27.4 & & 0 & 42.5 & \\
\hline Stage $3 a$ & 0 & 50.0 & & 0 & 32.2 & \\
\hline Stage 3b & 0 & 6.5 & & 0 & 8.0 & \\
\hline Stage 4 & 0 & 1.6 & & 0 & 0 & \\
\hline Stage 5 & 0 & 0 & & 0 & 0 & \\
\hline
\end{tabular}

2 women (age, 29 and 63 years) with levels of approximately $45 \mathrm{~mL} / \mathrm{min} / 1.73 \mathrm{~m}^{2}$ at baseline. There was no significant difference in primary kidney diseases (i.e., kidney disease without HT or DM) between men and women (33.3\% vs. 38.3\%).

Regression analysis demonstrated that change in eGFR over 3 years was significantly correlated with ACR in men without CKD (change in eGFR $=-1.170+0.378 \times$ ACR, $P<0.015$, $r^{2}=0.037$ ) and with CKD (change in eGFR $=-1.707+0.022 \times$ ACR, $P<0.001, r^{2}=0.201$ ), and with $\mathrm{Hb}$ and ACR in women with CKD (change in eGFR $=48.870-3.803 \times \mathrm{Hb}+0.018 \times \mathrm{ACR}, P<0.05$, $\left.r^{2}=0.134\right)$. There was no significant correlation in women without CKD ( $\left.\mathrm{Hb}: P=0.055\right)$.

\section{Discussion}

From a public health perspective, the IKEAJ CKD detection program was seen to be beneficial because participants with CKD experienced a significant decrease in ACR level and maintained a consistent eGFR level over the 3 years of follow up. In addition, 


\section{Kidney \\ Blood Pressure Research}

Table 2. Changes of poor-controlled blood pressure, blood glucose, and low-density lipoprotein-cholesterol levels in patients with and without chronic kidney disease

\begin{tabular}{|c|c|c|c|c|c|c|c|}
\hline & & & & $\operatorname{ar} 0$ & Year 1 & Year 2 & Year 3 \\
\hline \multirow{4}{*}{$\begin{array}{l}\text { Poorly } \\
\text { controlled blood } \\
\text { pressure }\end{array}$} & CKD (-) men & $61(37.5 \%)$ & $\begin{array}{l}\text { New onset } \\
\text { Diagnosis }\end{array}$ & $\begin{array}{l}22(36.1 \%) \\
39(63.9 \%)\end{array}$ & 25 (15.4\%) & $30(18.2 \%)$ & $11(6.8 \%)$ \\
\hline & CKD (+) men & $24(38.7 \%)$ & $\begin{array}{l}\text { New onset } \\
\text { Diagnosis }\end{array}$ & $\begin{array}{l}2(8.3 \%)^{* *} \\
22(91.7 \%)^{* *}\end{array}$ & $15(24.2 \%)$ & $9(14.5 \%)$ & $6(9.7 \%)$ \\
\hline & CKD (-) women & $51(23.0 \%)$ & $\begin{array}{l}\text { New onset } \\
\text { Diagnosis }\end{array}$ & $\begin{array}{l}21(41.2 \%) \\
30(58.8 \%)\end{array}$ & $35(15.8 \%)$ & $35(15.8 \%)$ & $35(15.8 \%)$ \\
\hline & $\begin{array}{l}\text { CKD (+) } \\
\text { women }\end{array}$ & $38(43.7 \%)$ & $\begin{array}{l}\text { New onset } \\
\text { Diagnosis }\end{array}$ & $\begin{array}{l}7(18.4 \%)^{*} \\
31(81.6 \%)^{*}\end{array}$ & $23(26.4 \%)$ & $23(26.4 \%)$ & $19(21.8 \%)$ \\
\hline \multirow{4}{*}{$\begin{array}{l}\text { Poorly } \\
\text { controlled blood } \\
\text { glucose }\end{array}$} & CKD $(-)$ men & $18(11.1 \%)$ & $\begin{array}{l}\text { New onset } \\
\text { Diagnosis }\end{array}$ & $\begin{array}{l}3(16.7 \%) \\
15(83.3 \%)\end{array}$ & $19(11.7 \%)$ & $22(13.9 \%)$ & $29(17.9 \%)$ \\
\hline & CKD (+) men & $9(14.5 \%)$ & $\begin{array}{l}\text { New onset } \\
\text { Diagnosis }\end{array}$ & $\begin{array}{l}1(11.1 \%) \\
8(88.9 \%)\end{array}$ & $9(14.5 \%)$ & $9(14.5 \%)$ & $10(16.1 \%)$ \\
\hline & CKD (-) women & $12(5.4 \%)$ & $\begin{array}{l}\text { New onset } \\
\text { Diagnosis }\end{array}$ & $\begin{array}{l}1(8.3 \%) \\
11(91.7 \%)\end{array}$ & $19(8.6 \%)$ & $18(8.1 \%)$ & 19 (8.6\%) \\
\hline & $\begin{array}{l}\text { CKD (+) } \\
\text { women }\end{array}$ & $8(9.2 \%)$ & $\begin{array}{l}\text { New onset } \\
\text { Diagnosis }\end{array}$ & $\begin{array}{l}7(18.4 \%) \\
31(81.6 \%)\end{array}$ & $12(13.8 \%)$ & $13(14.9 \%)$ & $13(14.9 \%)$ \\
\hline \multirow{4}{*}{$\begin{array}{l}\text { Poorly } \\
\text { controlled low- } \\
\text { density } \\
\text { lipoprotein- } \\
\text { cholesterol }\end{array}$} & CKD (-) men & $26(16.0 \%)$ & $\begin{array}{l}\text { New onset } \\
\text { Diagnosis }\end{array}$ & $\begin{array}{l}21(80.8 \%) \\
5(19.2 \%)\end{array}$ & $23(14.2 \%)$ & $20(12.3 \%)$ & 27 (16.7\%) \\
\hline & CKD $(+)$ men & $8(12.9 \%)$ & $\begin{array}{l}\text { New onset } \\
\text { Diagnosis }\end{array}$ & $\begin{array}{l}7(87.5 \%) \\
1(12.5 \%)\end{array}$ & $8(12.9 \%)$ & $8(12.9 \%)$ & $6(9.7 \%)$ \\
\hline & CKD (-) women & $51(23.0 \%)$ & $\begin{array}{l}\text { New onset } \\
\text { Diagnosis }\end{array}$ & $\begin{array}{l}37(72.5 \%) \\
14(27.5 \%)\end{array}$ & $36(16.2 \%)$ & $40(18.0 \%)$ & $38(17.1 \%)$ \\
\hline & $\begin{array}{l}\text { CKD (+) } \\
\text { women }\end{array}$ & $25(28.7 \%)$ & $\begin{array}{l}\text { New onset } \\
\text { Diagnosis }\end{array}$ & $\begin{array}{l}10(40.0 \%)^{*} \\
15(60.0 \%)^{*}\end{array}$ & $18(20.7 \%)$ & 17 (19.5\%) & $12(13.8 \%)$ \\
\hline
\end{tabular}

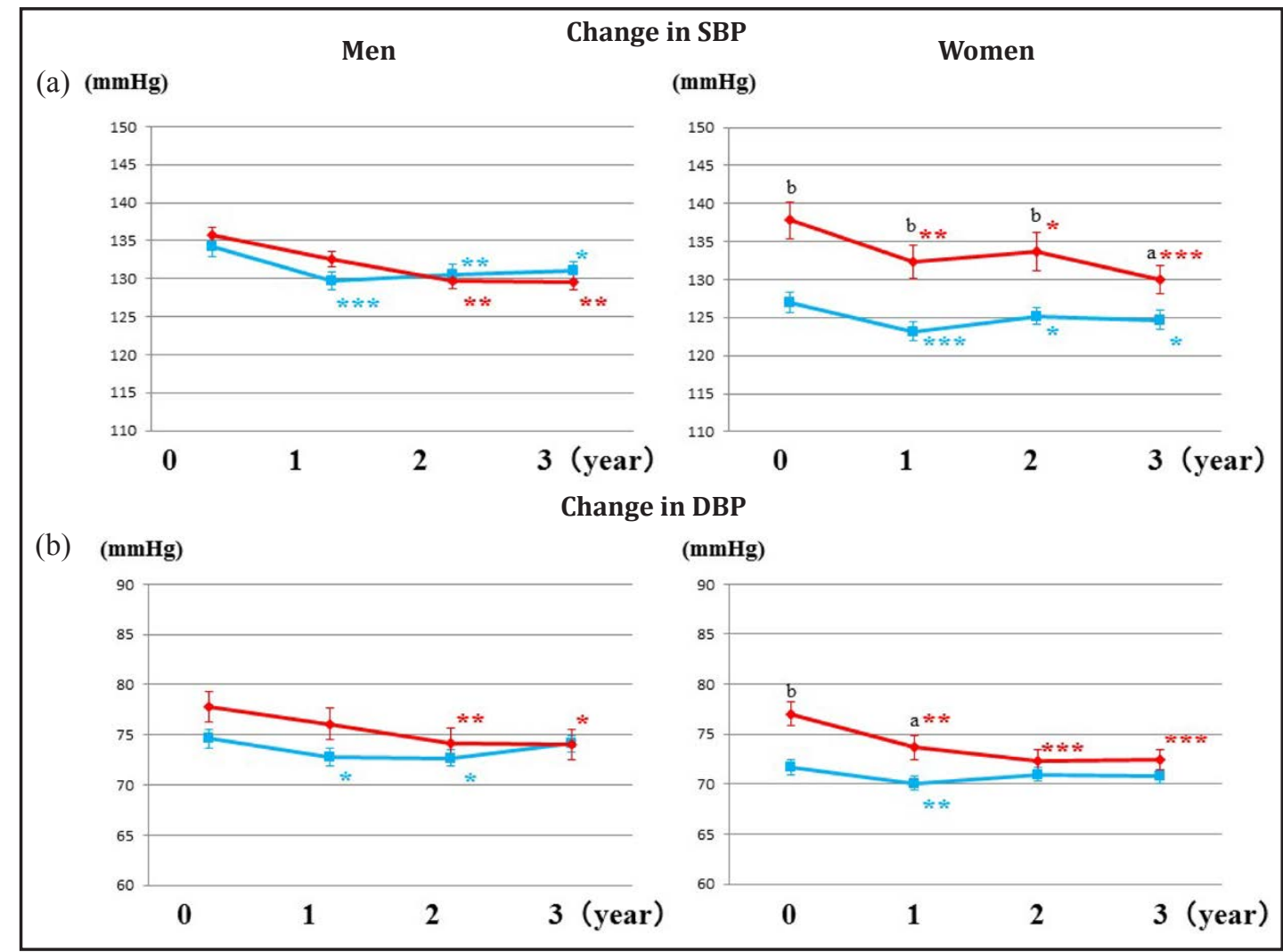

Fig. 1. Change in systolic (a) and diastolic (b) blood pressure in participants with and without chronic kidney disease (CKD). - (red) CKD (+) — (blue) CKD (-); ${ }^{*} P<0.05$ vs. baseline, ${ }^{* *} P<0.01$ vs. baseline, ${ }^{* * *} P<0.001$ vs. baseline, ${ }^{* \mathrm{a}} P<0.05$ CKD (-) vs. CKD (+), ${ }^{\mathrm{b}} P<0.001$ CKD (-) vs. CKD (+) . 


\section{Kidney Blood Pressure Research}

Kidney Blood Press Res 2014;39:279-288

DOI: 10.1159/000355805

Publisned onIIne: August 23, 2014

C 2014 S. Karger AG, Basel

www.karger.com/kbr
Fig. 2. Change in hemoglobin A1c in participants with and without chronic kidney disease (CKD). ( (red) CKD $(+)$ • (blue) CKD (-); ${ }^{*} P<0.05$ vs. baseline, ${ }^{*} P<0.01$ vs. baseline, ${ }^{* * *} P<0.001$ vs. baseline, $\quad{ }^{\mathrm{a}} P<0.05$ CKD (-) vs. CKD (+).

Fig. 3. Change in low-density lipoprotein-choles terol (LDL-C) in participants with and without chronic kidney disease (CKD). - (red) CKD $(+)$ - (blue) CKD (-); ${ }^{*} P<0.05$ vs. baseline, ${ }^{* *} P<0.01$ vs. baseline, ${ }^{* * *} P<0.001$ vs. baseline.

Fig. 4. Change in urine albumin-creatinine ratio (ACR) in participants with and without chronic kidney disease (CKD). - (red) CKD $(+)$ - (blue) CKD (-); ${ }^{*} P<0.05$ vs. baseline, ${ }^{* *} P<0.01$ vs. baseline, ${ }^{* * *} P<0.001$ vs. baseline, $\quad{ }^{\mathrm{a}} P<0.001$ CKD (-) vs. CKD (+).

Fig. 5. Change in estimated glomerular filtration rate (eGFR) in participants with and without chronic kidney disease (CKD). • (red) CKD (+) घ (blue) CKD (-); ${ }^{*} P<0.05$ vs. baseline, $\quad * * P<0.01$ vs. baseline, *** $P<0.001$ vs. baseline, ${ }^{\mathrm{a}} P<0.001 \mathrm{CKD}$ (-) vs. CKD (+).
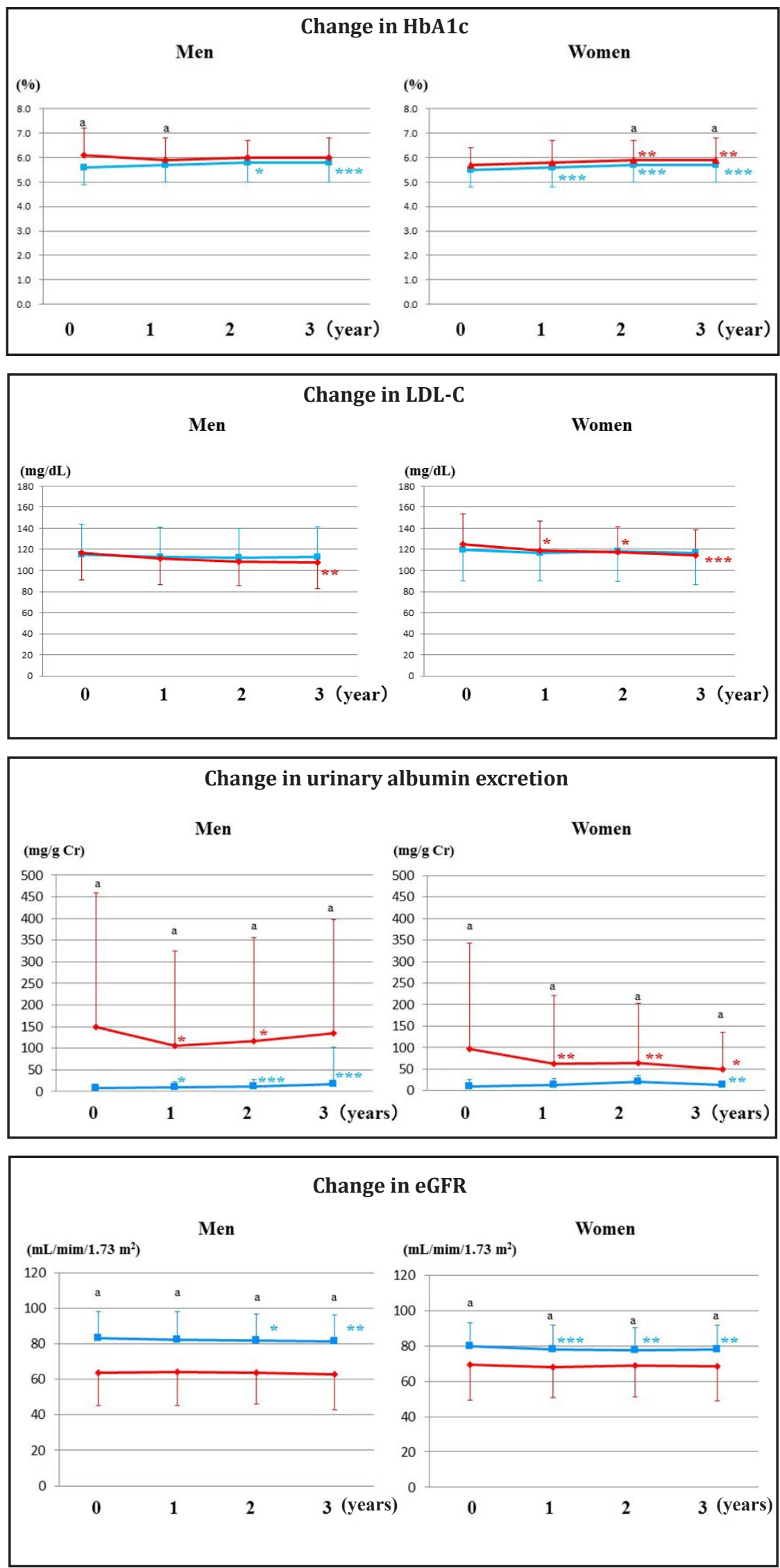


\section{Kidney Blood Pressure Research}

Kidney Blood Press Res 2014;39:279-288

DOI: 10.1159/000355805

Publisned ontıne: August 23, 2014

(C) 2014 S. Karger AG, Basel

www.karger.com/kbr

Okada/Yanai/Takeuchi/Matsuyama/Nitta/Hayashi/Takahashi: Relationship Between Hemoglobin and eGFR in Women we demonstrated that the risk factors for decreasing eGFR are ACR in men and ACR and $\mathrm{Hb}$ in women. Because the mean ACR and eGFR levels were $149.2 \mathrm{mg} / \mathrm{g} \mathrm{Cr}$ and $63.8 \mathrm{~mL} / \mathrm{min} / 1.73 \mathrm{~m}^{2}$ in men with CKD and $96.7 \mathrm{mg} / \mathrm{g} \mathrm{Cr}$ and $69.4 \mathrm{~mL} / \mathrm{min} / 1.73 \mathrm{~m}^{2}$ in women with CKD, renal dysfunction was very mild. The mean $\mathrm{Hb}$ level at baseline in women with CKD was within the normal range $(13.0 \mathrm{~g} / \mathrm{dL})$. BMI, waist circumference, SBP, DBP, Hb, HDL-C, LDL-C, and HbA1c were well controlled in many participants. In the IKEAJ program, many baseline parameters were found to be different in participants with and without CKD and between sexes. It is therefore necessary to consider these differences when examining the progression of CKD.

Anemia is common among advancedstage CKD patients and is a known risk factor for morbidity and mortality. Even mild anemia has been reported to increase the risk of progression of ESKD in patients with DM independently of sex [8]. That study included patients who already had a moderately decreased eGFR. In contrast, there are no reports identifying a sex difference in mild anemia as a risk factor for ESKD in people with relatively preserved eGFR levels $(>60$ $\mathrm{mL} / \mathrm{min} / 1.73 \mathrm{~m}^{2}$ ). Our data indicate that the slight decreases of $\mathrm{Hb}$ and mild anemia are independent predictors of decreasing eGFR in only women with early-stage CKD. Anemia is a modifiable risk factor that can be treated
Table 3. Percentage of participants by stage of chronic kidney disease

\begin{tabular}{|c|c|c|c|c|}
\hline & Year 0 & Year 1 & Year 2 & Year 3 \\
\hline \multicolumn{5}{|c|}{ Men without CKD at baseline } \\
\hline CKD (-) & 100 & 92.6 & 88.9 & 90.1 \\
\hline Stage 1 & 0 & 1.2 & 1.9 & 0.6 \\
\hline Stage 2 & 0 & 2.5 & 4.3 & 4.9 \\
\hline Stage 3a & 0 & 3.7 & 3.7 & 4.3 \\
\hline Stage $3 b$ & 0 & 0 & 1.2 & 0 \\
\hline Stage 4 & 0 & 0 & 0 & 0 \\
\hline Stage 5 & 0 & 0 & 0 & 0 \\
\hline \multicolumn{5}{|c|}{ Men with CKD at baseline } \\
\hline CKD (-) & 0 & 19.4 & 17.7 & $19.4^{* *}$ \\
\hline Stage 1 & 14.5 & 11.3 & 9.7 & 6.5 \\
\hline Stage 2 & 27.4 & 19.4 & 25.8 & 24.2 \\
\hline Stage 3a & 50.0 & 41.9 & 37.1 & 33.9 \\
\hline Stage $3 b$ & 6.5 & 4.8 & 8.1 & 12.9 \\
\hline Stage 4 & 1.6 & 3.2 & 1.6 & 3.2 \\
\hline Stage 5 & 0 & 0 & 0 & 0 \\
\hline \multicolumn{5}{|c|}{ Women without CKD at baseline } \\
\hline CKD $(-)$ & 100 & 89.6 & 85.6 & 84.2 \\
\hline Stage 1 & 0 & 0.9 & 1.4 & 1.8 \\
\hline Stage 2 & 0 & 4.1 & 8.1 & 7.7 \\
\hline Stage 3a & 0 & 5.0 & 5.0 & 6.3 \\
\hline Stage $3 b$ & 0 & 0.5 & 0 & 0 \\
\hline Stage 4 & 0 & 0 & 0 & 0 \\
\hline Stage 5 & 0 & 0 & 0 & 0 \\
\hline \multicolumn{5}{|c|}{ Women with CKD at baseline } \\
\hline CKD (-) & 0 & 29.9 & 29.9 & $39.1^{* *}$ \\
\hline Stage 1 & 17.2 & 4.6 & 10.3 & 5.7 \\
\hline Stage 2 & 42.5 & 24.1 & 25.3 & 18.4 \\
\hline Stage $3 a$ & 32.2 & 34.5 & 28.7 & 27.6 \\
\hline Stage $3 b$ & 8.0 & 6.9 & 5.7 & 6.9 \\
\hline Stage 4 & 0 & 0 & 0 & 2.3 \\
\hline Stage 5 & 0 & 0 & 0 & 0 \\
\hline
\end{tabular}

Table 4. Comparison of values of men and women a with cured status of chronic kidney disease at years 0 and 3

\begin{tabular}{|c|c|c|c|c|c|c|}
\hline & & len $(n=12)$ & & & omen $(n=34$ & \\
\hline & Year 0 & Year 3 & $\begin{array}{c}\mathrm{P} \\
\text { value }\end{array}$ & Year 0 & Year 3 & $P$ value \\
\hline Age (years) & $62.8 \pm 3.9$ & & & $59.3 \pm 2.7$ & & \\
\hline Body mass index & $26.3 \pm 1.8$ & $26.2 \pm 1.9$ & ns & $23.7 \pm 0.7$ & $22.9 \pm 0.6^{*}$ & $P<0.001$ \\
\hline Waist circumstance $(\mathrm{cm})$ & $90.2 \pm 3.8$ & $88.9 \pm 4.0$ & ns & $84.0 \pm 2.1$ & $81.4 \pm 1.8$ & ns \\
\hline Systolic blood pressure ( $\mathrm{mmHg}$ ) & $129.3 \pm 4.2$ & $123.7 \pm 3.5$ & ns & $134.8 \pm 4.0$ & $124.2 \pm 2.6$ & $\mathrm{P}<0.001$ \\
\hline Diastolic blood pressure (mmHg) & $74.7 \pm 3.5$ & $74.0 \pm 3.5$ & ns & $77.3 \pm 1.9$ & $71.8 \pm 1.4$ & $P<0.001$ \\
\hline Hemoglobin $(\mathrm{g} / \mathrm{dL})$ & $14.4 \pm 0.4$ & $14.3 \pm 0.4$ & ns & $13.4 \pm 0.2^{*}$ & $12.4 \pm 0.5^{* *}$ & $\mathrm{P}<0.05$ \\
\hline HDL cholesterol (mg/dL) & $51.8 \pm 5.8$ & $57.3 \pm 8.8$ & ns & $62.1 \pm 3.0$ & $61.7 \pm 27$ & ns \\
\hline LDL cholesterol $(\mathrm{mg} / \mathrm{dL})$ & $118.9 \pm 7.9$ & $125.6 \pm 10.0$ & ns & $123.9 \pm 4.3$ & $112.3 \pm 3.5$ & $\mathrm{P}<0.01$ \\
\hline Hemoglobin A1c (\%) & $5.7 \pm 0.1$ & $5.6 \pm 0.1$ & ns & $5.5 \pm 0.1$ & $5.8 \pm 0.2$ & $\mathrm{P}<0.01$ \\
\hline $\begin{array}{l}\text { Estimated glomerular filtration rate } \\
\left(\mathrm{mL} / \mathrm{min} / 1.73 \mathrm{~m}^{2}\right)\end{array}$ & $71.0 \pm 4.5$ & $73.9 \pm 4.7$ & ns & $80.0 \pm 3.5$ & $80.6 \pm 2.7$ & ns \\
\hline Urinary albumin excretion (mg/g Cr) & $48.7 \pm 19.0$ & $13.2 \pm 2.6$ & ns & $60.3 \pm 9.2$ & $14.1 \pm 1.3$ & $\mathrm{P}<0.001$ \\
\hline
\end{tabular}




\section{Kidney Blood Pressure Research}

Fig. 6. Cured cases of chronic kidney disease (CKD) at year 3. (a) Change in urine albumin-creatinine ratio (ACR); - (red) CKD cured cases with ACR decreasing below $30 \mathrm{mg} / \mathrm{g} \mathrm{Cr}$, ○ (blue) CKD cured cases with estimated glomerular filtration rate (eGFR) increasing over $60 \mathrm{~mL} /$ $\min / 1.73 \mathrm{~m}^{2}$. (b) Change in estimated glomerular filtration rate; • (red) CKD cured cases with eGFR increasing over $60 \mathrm{~mL} / \mathrm{min} / 1.73 \mathrm{~m}^{2}$, o (blue) CKD cred cases with ACR decreasing below $30 \mathrm{mg} / \mathrm{g} \mathrm{Cr}$.

Okada/Yanai/Takeuchi/Matsuyama/Nitta/Hayashi/Takahashi: Relationship Between

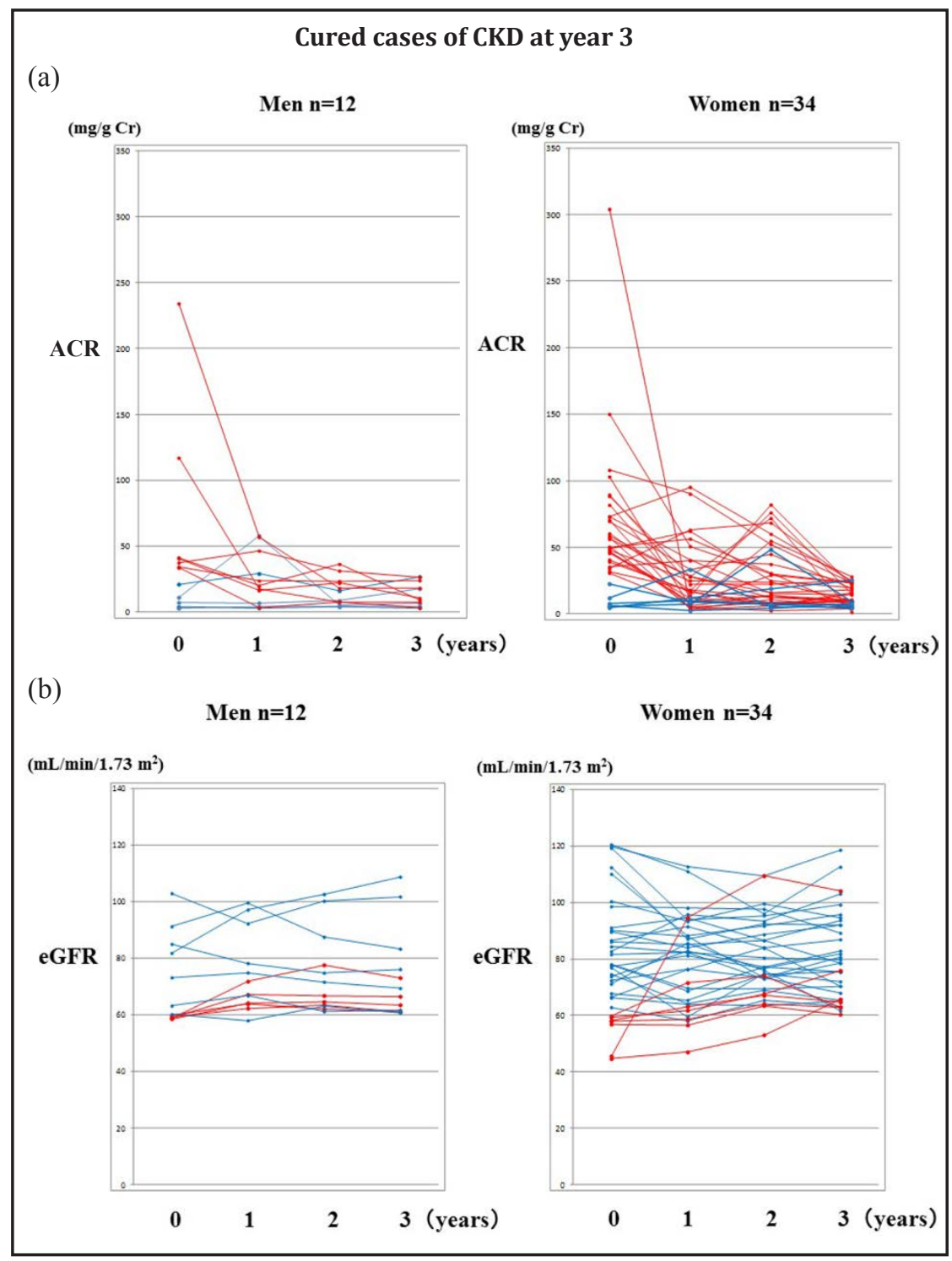

or prevented by erythropoiesis-stimulating agents and correction of iron status. Because iron deficiency anemia often appears in women, we suggest that it is responsible for the iron deficiency anemia we observed in this study. Further investigation is needed of the relationships between anemia, iron status, and the progression of early-stage CKD in women.

BP in men and women with and without CKD decreased significantly over the course of this program, indicating that the program is effective for BP control. HbA1c levels in men and women with and without CKD increased significantly. LDL-C levels in men and women with CKD were significantly reduced and therefore this program appears to be effective for promoting control of LDL-C in CKD participants. Taken together, the IKEAJ program is a useful public health activity that can benefit participants with and those without CKD.

The influence of sex differences on the incidence of CKD is not well understood, although it is known that men and women with CKD have differing rates of renal dysfunction progression. It has been reported that women have a lower risk of progression than men [8]. On the other hand, at least one study reported that CKD progresses more rapidly in women of postmenopausal age than in men [9]. A meta-analysis demonstrated that men with CKD of various etiologies show a more rapid decline in renal function than women with CKD over time [10]. It has been suggested that these sex differences are associated with not only 


\section{Kidney Blood Pressure Research}

Kidney Blood Press Res 2014;39:279-288

DOI: 10.1159/000355805

Published onlIne: August 23, 2014

(C) 2014 S. Karger AG, Basel

www.karger.com/kbr

Okada/Yanai/Takeuchi/Matsuyama/Nitta/Hayashi/Takahashi: Relationship Between Hemoglobin and eGFR in Women

HT, DM, dyslipidemia, and dietary factors but also with renal structure and function, direct cellular effects of sex hormones, the renin-angiotensin system, prostaglandins, cytokines and growth factors, and estrogens [8]. Although the mechanisms by which sex differences influence the progression of CKD are not well understood, treatments such as salt restriction remain the same. In the present study, we found no significant difference in the incidence and progression of CKD between sexes, although more men had advanced-stage CKD than women.

There are rare reports of CKD, in relation to microalbuminuria and eGFR, being cured. In the present study, significantly more women with CKD than men were cured at 3 years, although no significant difference was observed in the progression of CKD between men and women without CKD. Although the progression of CKD is clearly dependent on primary kidney disease, in men and women who attained a cured status, their past history of primary kidney disease was similar. It has been reported that mortality rises exponentially with decreasing eGFR below $60 \mathrm{~mL} / \mathrm{min} / 1.73 \mathrm{~m}^{2}$, while albuminuria shows a linear association [11] and eGFR below $60 \mathrm{~mL} / \mathrm{min} / 1.73 \mathrm{~m}^{2}$ has been independently associated with hospitalization, cardiovascular events, and death [12]. Because the level of eGFR did not recover to greater than $60 \mathrm{~mL} / \mathrm{min} / 1.73 \mathrm{~m}^{2}$ except in some women, interventions for CKD patients should be implemented before their eGFR level decreases to $60 \mathrm{~mL} / \mathrm{min} / 1.73 \mathrm{~m}^{2}$.

The IKEAJ CKD detection program is beneficial because it can prevent increases in ACR and decreases in eGFR levels over 3 years. Focusing on a high-risk population detected a high prevalence of CKD. These program data also demonstrated that CKD is a public health issue in Japan and that management is inadequate. Family doctors had achieved poor control of BP, BG, and lipid levels of the patients with CKD, indicating the need to educate family doctors and patients on the control of these factors. Our results suggest that the slight decrease of $\mathrm{Hb}$ within a normal range and mild anemia can be managed in women with early-stage CKD and that there could be a need for intervention for CKD patients before their eGFR levels decrease to $60 \mathrm{~mL} / \mathrm{min} / 1.73 \mathrm{~m}^{2}$. In addition, we may need to treat mild anemia in women with CKD at an early stage, even if their $\mathrm{Hb}$ level is within normal range. We believe that if this reduction of Hb could be prevented, ACR level and eGFR level would decrease or increase further, respectively, in women with cured status. Long-term follow up of the population by assessing CKD detection efforts, treatment, and control of risk factors is also needed in order to determine the impact of public health awareness programs. Last year, the Ministry of Health, Labour and Welfare invited public participation throughout the country to identify a practical project for preventing exacerbation of CKD. IKEAJ was selected as a project operator and has just started prospective investigations into the influence of the lifestyle and diet on the progression of CKD stages 1 to 4 .

\section{Conclusion}

CKD prevalence and progression rate were not different between sexes. But, significantly more women with CKD had a "cured" status than men with CKD. Most whose eGFR increased to $>60 \mathrm{~mL} / \mathrm{min} / 1.73 \mathrm{~m}^{2}$ had values just below those at baseline. Regression analysis showed that change in eGFR correlated significantly with ACR in men with CKD and with Hb and ACR in women with CKD. These results suggest that the slight decrease of $\mathrm{Hb}$ within a normal range and mild anemia can be managed in women with early-stage CKD. The key baseline for eGFR is $60 \mathrm{~mL} / \mathrm{min} / 1.73 \mathrm{~m}^{2}$.

\section{Disclosure Statement}

All the authors declared no competing interests. 


\section{Kidney \\ Blood Pressure Research}

Kidney Blood Press Res 2014;39:279-288

\begin{tabular}{l|l}
\hline DOI: $10.1159 / 000355805$ & (c 2014 S. Karger AG, Basel \\
\hline
\end{tabular}

Publisned online: August 23, 2014

www.karger.com/kbr

Okada/Yanai/Takeuchi/Matsuyama/Nitta/Hayashi/Takahashi: Relationship Between Hemoglobin and eGFR in Women

\section{References}

1 National Kidney Foundation: K/DOQI clinical practice guidelines for chronic kidney disease; evaluation, classification and stratification. Am J Kidney Dis 2002;39:S1-S266.

2 Levey AS, Eckardt KU, Tsukamoto Y, Levin A, Coresh J, Rossert J, De Zeeuw D, Hostetter TH, Lameire N, Eknoyan G: Definition and classification of chronic kidney disease: a position statement from kidney disease improving global outcomes (KDIGO). Kidney Int 2005;67:2089-2100.

3 KDIGO 2012 Clinical Practice Guideline for the Evaluation and Management of Chronic Kidney Disease: Summary of Recommendation Statements. Kidney Int 2013;84:S5-S14.

4 Takahashi S, Okada K, Yanai M: The Kidney Early Evaluation Program (KEEP) of Japan: results from the initial screening period. Kidney Int 2010;77:S17-S23.

5 Yamagata K, Ishida K, Sairenchi T, Takahashi H, Ohba S, Shiigai T, Narita M, Koyama A: Risk factors for chronic kidney disease in a community-based population: a 10-year follow-up study. Kidney Int 2007;71:159-166.

6 Nakai S, Iseki K, Itami N, Ogata S, Kazama JJ, Kimata N, Shigematsu T, Shinoda T, Shoji T, Suzuki K, Taniguchi M, Tsuchida K, Nakamoto H, Nishi H, Hashimoto S, Hasegawa T, Hanafusa N, Hamano T, Fujii N, Masakane I, Marubayashi S, Morita O, Yamagata K, Wakai K, Wada A, Watanabe Y, Tsubakihara Y: An overview of regular dialysis treatment in Japan (as of 31 December 2010). Ther Apher Dial 2012;16:483-521.

7 Matsuo S, Imai E, Horio Y, Yasuda Y, Tomita K, Nitta K, Yamagata K, Tomino Y, Yokoyama H, Hishida A: Revised equation for estimated GFR from serum creatinine in Japan. Am J Kidney Dis 2009;53:982-992.

8 Silbiger S, Neugarten J: The impact of gender on the progression of chronic renal disease. Am J Kidney Dis 1995;25:515-533.

-9 Jafar TH, Schmid CH, Stark PC, Toto R, Remuzzi G, Ruggenenti P, Marcantoni C, Becker G, Shahinfar S, de Jong PE, de Zeeuw D, Kamper AL, Strangaard S, Levey AS: The rate of progression of renal disease may be slower in women compared with men: a patient-level meta-analysis. Nephrol Dial Transplant 2003;18:2047-2053.

-10 Neugarten J, Acharya A, Silbiger SR: Effect of gender on the progression of nondiabetic renal disease: a meta-analysis. J Am Soc Nephrol 2000;11:319-329.

11 Matsushita K, van der Velde M, Astor BC, Woodward M, Levey AS, de Jong PE, Coresh J, Gansevoort RT: Association of estimated glomerular filtration rate and albuminuria with all-cause and cardiovascular mortality in general population cohorts: a collaborative meta-analysis. Lancet 2010;375:2073-2081.

12 Go AS, Chertow GM, Fan D, McCulloch CE, Hsu CY: Chronic kidney disease and the risks of death, cardiovascular events, and hospitalization. N Engl J Med 2004;351:1296-1305. 